\title{
Institutional Arrangements and Management of Environmental Resources in Ethiopia
}

\author{
Sisay Nune Hailemariam ${ }^{1}$, Teshome Soromessa ${ }^{1} \&$ Demel Teketay $^{2}$ \\ ${ }^{1}$ Addis Ababa University, P. O. Box 1176, Addis Ababa, Ethiopia \\ ${ }^{2}$ Botswana University of Agriculture and Natural Resources, Department of Crop Science and Production, Private \\ Bag 0027, Gaborone, Botswana \\ Correspondence: Sisay Nune Hailemariam, Addis Ababa University, P. O. Box 1176, Addis Ababa, Ethiopia. Tel: \\ 251-911-2919-4379. Email: nune.sisay@gmail.com
}

Received: February 6, 2016 Accepted: February 26, 2016 Online Published: February 29, 2016

doi:10.5539/enrr.v6n1p67 URL: http://dx.doi.org/10.5539/enrr.v6n1p67

\begin{abstract}
The study was conducted in three main eco-regions, namely Bale Mountains, South-West and Semien Eco-Regions in Ethiopia with the following objectives - to: (i) review the current institutional arrangements in terms of rights and responsibilities, planning system, capacity, and motivation of local communities for the management of environmental resources in Ethiopia in general, and the forest sector in particular and (ii) assess constraints for the successful implementation of policies/legislation, strategies, programs, projects and actions at a landscape level. Focus group discussion and semi-structured questionnaires were used to collect data. Purposive sampling method was employed to select respondents. Environmental resources conservation and management (ERCM) institutions considered in this study were agriculture and natural resources, water, irrigation and electricity, land and environmental protection, local administration, and road authorities. Within the above-mentioned institutions a total of 56 questionnaires were administered and 48 interviews were conducted. The results show that the capacity of the existing institutions is constrained by lack of clear rights and responsibilities, absence of common result framework, absence of common planning system, high staff turnover, absence of spatial planners and failure to respond to the demands of community-based organizations. The institutional arrangements need critical review and analyses in order to design responsible institutions for ERCM at all levels, which includes availing knowledgeable and all-rounded professionals at all levels, with proper incentive mechanisms, who would be able to cope with future challenges emanating from climate change and other social tensions.
\end{abstract}

Keywords: capacity, Environmental Resources Conservation and Management, institutions, interest, planning, responsibilities, rights

\section{Introduction}

\subsection{Background}

The causes of ecosystem degradation are rooted in an economic system that often rewards exploitation rather than stewardship of natural system (World Resources Institute [WRI], 2003). Agriculture expansion and intensification threatens environmental goods and services. Drivers of deforestation and forest degradation are mostly related with large \& small scale agricultural investments and road construction, amongst others (Geist \& Lambin, 2001) The knock-on effects of the expansion and intensification of agriculture range from affecting livelihoods and health to disrupting the supply of future food need (Sayer et al., 2013; Tscharntke, et al., 2012).

FAO has projected food requirements in 2050 to increase by $70 \%$ from current production (FAO, 2009). To produce the required amount, some forest and other land uses outside of cropland may be converted to agriculture that, in turn, may affect ecosystems. To some extent, urbanization is also competing land use. The biomass energy in Africa is another major cause for degradation in the absence of sustainable forest management. In Ethiopia, it is recognized as the second most important cause of forest loss (Ministry of Natural Resources Development and Environmental Protection [MoNRDEP], 1994). For many years, the ecosystem services, particularly forest ecosystems, were given little attention. One of the many reasons is mostly linked with institutional arrangements, 
amongst others. Governance failures and lack of institutional capacity were identified as the primary constraints/obstacles to the implementation of the landscape approach (Sayer, et al., 2013).

Climate changes recently have widespread impacts on human and natural systems (IPCC, 2015). The advisory services to smallholder farmers and politicians from the institutions mandated to do so concerning climate change adaptation and mitigation is not satisfactory. In most cases, "Business As Usual" mode of implementations is a norm. Landscape level management strategies and decisions will include making choices about the nature and timing of changes to overall land use, taking into account information about who or what may stand to benefit (or lose) from environmental services (Simpson and Burpee, 2014).

Putting dedicated and accountable institutions in place has paramount importance to combat ever increasing climate change and fulfill the requirements of Post-2015 Sustainable Development Goals (SDGs). The institutions need to be equipped, not limited to, with state of art technologies to analyze current situation and future predictions regarding food security, climate change phenomena, market situation both at country, regional, and international levels. Their capacity to steer the management of holistic ecosystem, rather than a single sector, should be developed.

For example, current institutions responsible for environmental/ecosystem management in Ethiopia are requesting more capacity towards implementation of relevant programmes and projects as well as enforcement of laws. These institutions are housed at different organizations as a result of which common planning and programming has become difficult. The conflict between different institutions towards fulfilling their own goals may be more costly than had there been coordination and collaboration. Will-power and morality affect the degree to which people really act accordingly (Keizer, 2008).

\subsection{Problem Statement}

Absence of strong and dedicated institution for management of ecosystems or environmental resources (ERs) could lead to loss of natural assets, such as forests. Furthermore, in the absence of such institutions the ambition of a country towards better economic growth may put much pressure on ERs. For example, the desire to increase export products, such as coffee and tea became an agent of deforestation of intact forests in South-West Ethiopia after mid-1990s (Sherefa, 2007). However, production of cash crops could have been undertaken in lands that are not covered by forests had there been dedicated institutions, proper planning and monitoring of activities. In Ethiopia, the area under cultivation has increased by 1.4 million ha from 2004/05 to 2009/10 (Ministry of Finance and Economic Development [MoFED], 2010). A study on land cover change between 1977 and 2000 showed that areas covered by bare rock, soil and devoid of any vegetation has increased by $86.5 \%$, swamp area has shrunk by $51 \%$, high forest has decreased by $33.1 \%$ and shrub land has decreased by $83 \%$ (Woody Biomass Inventory and Strategic Planing Project [WBISPP], 2004). The majority of the increase in agricultural produces, especially crops, was achieved through the increase in agriculture lands which, in most cases, happened through conversion of forests and woodlands into agriculture lands (e.g. Kindu, Schneider, Teketay, \& Knoke, 2015; Ministry of Environment, Forest and Climate Change [MEFCC], 2016). Recent analysis shows that annual deforestation is approximately 85000ha in forests having 20 percent and more canopy closure (MEFCC, 2016).

Institutions are determined by the interests of those who are economically powerful (Keizer, 2008). For example, in Ethiopia, until recently, the power of Ministry of Agriculture (MoA) was stronger while institution (s) responsible solely for natural resources was either absent or without any financial resources and power. Additionally, lack of formal coordination amongst formal institutions, weak formal institutional capacity, weak/lack of cross sectoral coordination and inappropriate policies are identified as very serious constraints for implementation of landscape approaches (Sayer et al., 2013; Mekonnen \& Bluffstone, 2015; Federal Democratic Republic of Ethiopia [FDRE], 2015).

The interests of local communities matter most. Importance of local participation to manage natural resources is a proven approach for sustainability. World Resources Institute (WRI) has indicated that to have sustainability, making actors (e.g. communities) accountable through provision of access to environmental information and encouraging broad participation is vital (WRI, 2003). Insufficient information acquisition, management and dissemination, amongst others, are socio-economic and policy related factors of deforestation (Teketay, 2004-2005). In general, dedicated institution capable of generating information and evidence based data to link the community with policy maker interests probably is lacking. Among other things, having well-positioned institutions that can respond to various needs emerging from different interested groups while maintaining sustainability with prosperity might be the key for success (Ostrom, 2007).

Federal ministries that have vested interest on a particular landscape in Ethiopia are: (a) Ministry of Water, Irrigation and Electricity, (b) Ethiopian Wildlife Conservation Authority under the Ministry of Culture and 
Tourism (c) Ministry of Urban Planning and Housing, (d) Ministry of Agriculture and Natural Resources and (e) Ministry of Environment, Forest and Climate Change. All have gone through restructuring a number of times in the past. It is natural that institutions must constantly evolve to respond to changing circumstances (e.g. by protecting property rights), foster creativity, lower transaction costs and encourage the process of creative destruction (Boliari \& Topyan, 2007). However, when it is repeated and too much most institutional memories and capacity that was already in place might be lost (Teketay, 2004). Thus far, deforestation and forest degradation are still a concern (MEFCC, 2016). The above-mentioned institutions at all level (federal, regional and local) lack a system to plan together or the system may be inadequate. Staff turnover is another constraint hindering the institutions to discharge their responsibility.

The extension systems of ER institutions, among others, are weak to predict future challenges of the ever increasing, and alarming effects of climate change and environmental resources degradation and to advise the small holder farmers satisfactorily.

\subsection{Research Objectives}

Two specific objectives were designed, i.e. to: (i) review the current institutional arrangements' in terms of rights and responsibilities, planning system, capacity, and motivation of local communities for the management of environmental resources in Ethiopia in general (and the forest sector in particular) and (ii) assess constraints for the successful implementation of policies/legislation, strategies, programs, projects and actions at a landscape level.

\subsection{Research Questions}

Four research questions were tested in order to highlight the importance of institutional arrangement for effective Environmental resources conservation and management (ERCM) including sustainable implementation of forestry initiatives such as Reducing Emissions from Deforestation and forest Degradations (REDD+). The research questions were:

(1) Do all sector offices feel to have rights and responsibilities in the management of environmental resources (at all level)?

(2) Is there robust planning system within ERCM Institutions?

(3) Are the existing institutions capable of tackling the ever-increasing climate change and population growth, and meet the demands of the society?

(4) What motivates local communities to engage in environmental resources management in a landscape?

This research will join a number of researches already published on formal institutions dealing with ER. It shall contribute to discourse regarding ER management including REDD+. Our intention is to influence policy makers in two ways: i) well-capacitated institutions are extremely important for ER management; ii) institutional arrangements design must consider rights and responsibilities, robust planning system including common result framework, capacity and incentives. In this research the need for spatial planning came out as one of the priorities for ER management.

\section{Materials and Methods}

\subsection{Study Areas}

The study was carried out mainly in Bale Mountains Eco-Region (BMER), but also in Southern Eco-Region (SOER) and Semien Eco-Region (SER) (Figure 1). However, additional data were assessed at the federal, regional and, to some extent, zonal levels. The current governance structure of Ethiopia follows Federal system. Ethiopia has nine national regional states (NRSs) under which there are jurisdictional administrative boundaries called Zones. Under each zone, there are self-administered Districts called 'Woredas'. The size and number of woredas and zones differ from region to region.

BMER falls within two main zonal administrations namely, Bale and West-Arsi. The population of the two zonal administrations is estimated at 4,208,309 people, of which 50\% are female (Central Statistics Agency [CSA], 2015). The population within the four zones of south-west Ethiopia namely, Kafa, Sheka, Bench Maji and Illuababor is 3,603,285 people, of which females comprise 50.4\% (Central Statistics Agency, 2013). The population of the six woredas of North Gonder is estimated at 774,619 people of which $50 \%$ are female. Fertility rate in ANRS, ONRS and SNNPNRS has reached 4.2, 4.8 and 4.5\%, respectively (CSA, 2015).

According to Aalbaek (1993), the vegetation in the SOER found within three seed zones: Western Lower Broadleaved Afromontane Rainforest, Central Wet Broadleaved Afromontane Rainforest and Eastern Higher Broadleaved Afromontane Rainforest. Recent classification indicates that the area falls within two forest types 
namely, Transitional Rain Forest and Moist Evergreen Afromontane Forest (Friis, Demissew, \& van Breugel., 2011).

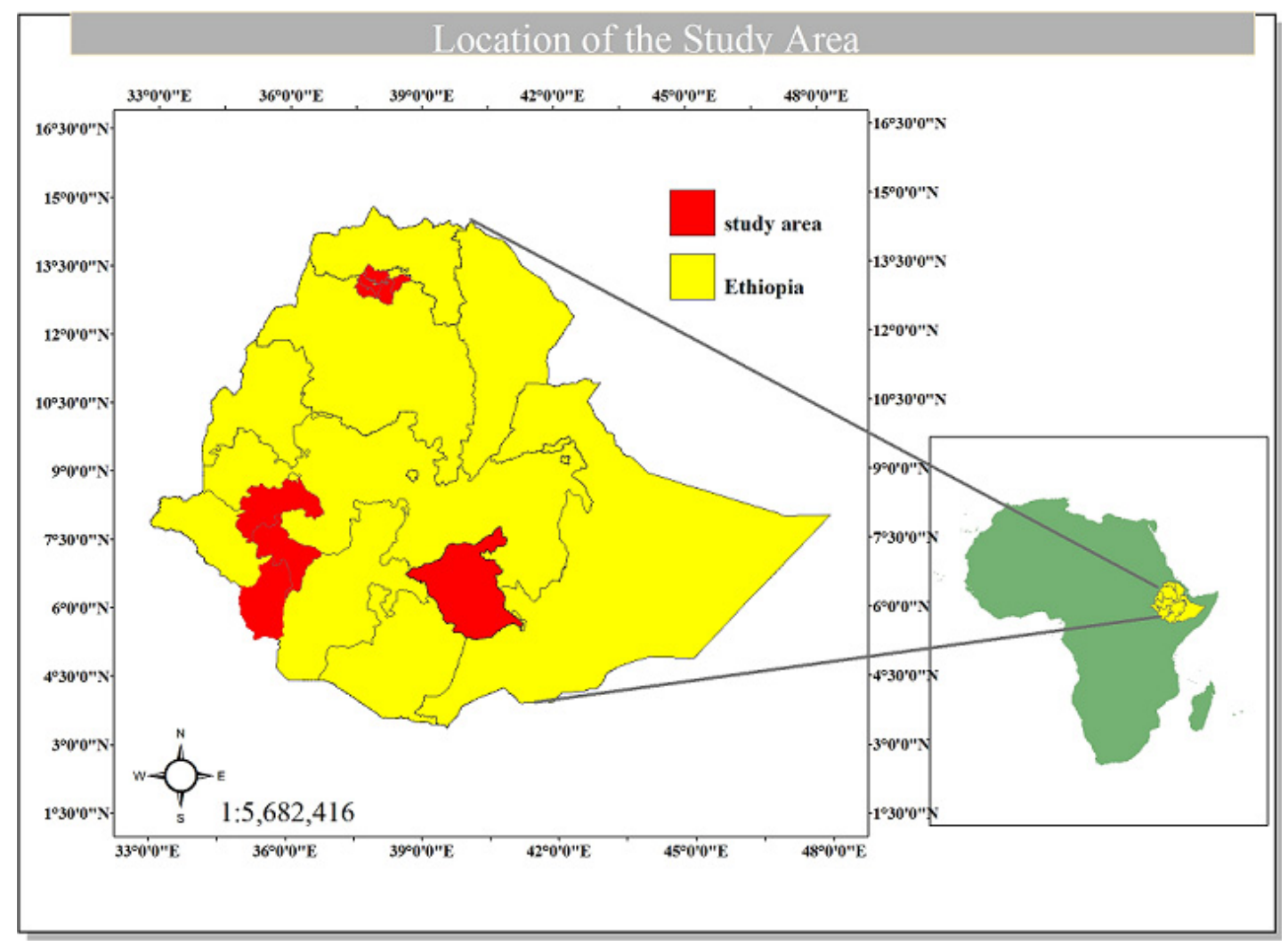

Figure 1. Location of the Study Areas

BMER comprises four vegetation zones namely, South-Eastern Upper Wet Broadleaved Afro Montane Rainforest, South-Eastern High Altitude Juniperus Forest, South-Eastern Lower Broadleaved Afro-Montane Rainforest and South-Eastern Lowlands Semi-Arid Woodlands (Aalbaek, 1993). According to Friis, et al. (2011), the area is classified as Dry Evergreen Afromontane Forest and Grassland Complex, and Moist Evergreen Afromontane Forest.

The majority of the SER falls under three major vegetation zones, namely, Tekeze Broadleaved Deciduous Woodlands, Western Lowland Broad-Leaved Deciduous Woodland and Western Highlands Moist Juniperus Forest (Aalbaek, 1993). Recently the area is classified as Dry Evergreen Afromontane Forest and Grassland Complex (Friis, et al., 2011).

The three eco-regions have significant importance for socio-economic development. The forest resources provide goods and services to rural population who are living in and around the forests. Non-timber forest products (NTFPs), such as honey, beeswax, gums and resins, spices and condiments are important products harvested, consumed and traded in large volumes every year from these eco-regions.

The mandate to administer environmental resources is vested in the power of NRSs in accordance with the Federal Laws enacted at the House of Parliament. House of Representatives (up to 550 seats) is the main and the only one institution that has power to approve and disapprove laws drafted by the executive. All laws need to be in accordance with the law of the land, the Constitution (FDRE, 1995). The members of the parliament are elected every five years within the country, from the nine Regional States. The laws are drafted and presented by (Federal level) the Ministry of Agriculture and Natural Resources Development (MoNRD), Ministry of Environment, Forest and Climate Change (MEFCC), Ministry of Water and Electricity, and Ministry of Culture and Tourism for sectors that are within their power.

Sectors, such as forest, agriculture, water, energy and wildlife are administered at the regional bureaus or authorities. NRSs have their own regional parliaments that decide the structure of sectors or offices suitable to their own socio-economic and geographic location. Annual budget for each sector is determined at the regional level 
unless it is earmarked from the federal level in the form of capital budgets. The sectoral offices at zonal and district levels follow more or less the same pattern as that of the regional levels.

The Oromia National Regional State (ONRS) comprises most of the forest and land resources in Ethiopia (WBISPP, 2004). The forest resources are mainly located in the south-eastern and south-western parts of Ethiopia. Therefore, whenever possible officials, otherwise experts at the regional level Bureau of Water, Irrigation and Energy (alternative energy sector), Bureau of Agriculture (natural resources sector) and Bureau of Environment and Land were interviewed. From South West Eco-Region, Illu-Ababor Zone was considered an ideal site for research since the zone comprises Regional Forest Priority Areas, such as Yayu, Sele Nono and Saylem (MoNRDEP, 1994). The forest resources comprise Coffea arabica L. and other important NTFPs that are very important for the livelihoods of the local communities. Because of unique forest and biodiversity values for the local economy as well as international significance, Yayu Forest has been designated as a UNESCO Biosphere Reserve (UNESCO, 2011).

Southern Nations Nationalities and People's National Regional State (SNNPNRS) is also endowed with substantial amount of environmental resources in addition to the diverse culture as well as ethnic composition. The forest resources in the south-western parts of the country are similar to forests in ONRS. Two forest areas, namely Kafa (UNESCO, 2011) and Shaka (UNESCO, 2012) Forests, have been designated as UNESCO Biosphere Reserves.

\subsection{Methods}

A number of topics were investigated to address the four research questions (Table 1).

Table 1. Research questions and topics of focus

\begin{tabular}{|c|c|}
\hline Research question & Topics of focus \\
\hline $\begin{array}{l}\text { 1. Do all sector offices feel to have } \\
\text { rights and responsibilities in the } \\
\text { management of environmental } \\
\text { resources (ERs) (at all level)? }\end{array}$ & $\begin{array}{l}\text { sector offices perception on rights and responsibilities; the level at } \\
\text { which their rights and responsibilities lay; } \\
\text { level at which decisions are made; and } \\
\text { whose rights matter most in the management of ERs; } \\
\text { whether there is necessity to establishing more community-based } \\
\text { organizations (CBOs) and strengthen the same for effective } \\
\text { management of ERs so that administrative burden on woredas and } \\
\text { authorities at higher levels shall be minimized. }\end{array}$ \\
\hline $\begin{array}{l}\text { 2. Is there robust planning system } \\
\text { within ERCM Institutions? }\end{array}$ & $\begin{array}{l}\text { if annual plans of one sector considered other environmental } \\
\text { resources of other institutions; } \\
\text { whether consultation mechanism exists where one sector consults } \\
\text { other sectors before that sector decides its annual plan or any } \\
\text { programme; } \\
\text { whether the existing planning and programming addresses the } \\
\text { interests of actors in a landscape; } \\
\text { if constraints exist to have common result framework for all } \\
\text { environmental resources; and } \\
\text { existence of satisfactory planning and programming to respond to } \\
\text { the ever increasing climate change and demands of society. }\end{array}$ \\
\hline $\begin{array}{l}\text { 3. Are the existing institutions } \\
\text { capable of tackling the } \\
\text { ever-increasing climate change and } \\
\text { population growth, and meet the } \\
\text { demands of the society? }\end{array}$ & $\begin{array}{l}>\text { if existing policies relevant to ERs can respond to the interest of } \\
\text { actors in a given landscape; } \\
\text { presence of performance measurement system to evaluate policies, } \\
\text { strategies, woreda plans implementation; } \\
\text { whether or not environmental impact assessment (EIA) is fully } \\
\text { implemented while specific projects and programmes are } \\
\text { implemented; } \\
\text { if the offices have capabilities to control negative impact on } \\
\text { wildlife, forests, soils and water; } \\
\text { if Ethiopia has skilled spatial planner with ability to engage at all } \\
\text { levels of development to deal with participation, consultation, } \\
\text { representation, and appeal; }\end{array}$ \\
\hline
\end{tabular}


$>$ if staff turnover is really a problem to limit the capacity of an institution;

$>$ institutional strength to enforce land use policies, the effectiveness of the land use and environmental protection departments in the eyes of the sector offices were assessed;

$>$ their views on whether or not paying just salary rather than rewards for the achievement make experts and responsible individuals in the environmental resource conservation and management (ERCM) lazy and if better payment for results achieved would improve the deliverables in any organization were assessed.

4. What motivates local communities to engage in environmental resources management in a landscape? incentives or penalties that motivate CBOs to discharge their responsibilities effectively;

$>$ consequences if a member household is absent from regular meetings;

frequency of community consultation whenever projects and programmes are implemented on matters that affects (positive or negative) the environment;

$>$ similar to land certification - would forest, wildlife and wetland certification for communities help to improve the sustainable use of ERCM?

With regards to focus group discussion, a total of 48 interviews were conducted, and the interview was made with only responsible Bureaus, Departments and Offices (focused on implementing entities) at regions, zones and woredas respectively (Figure 2). The number of FDG conducted in each study area is the followings: five in Bale; four in West Arsi; six in Kafa; five in Shaka; four in Bench Maji; two in SNNPNRS; 2 in ONRS; three in ANRS; two in Gonder Zone; four in Debark; three in Dabat; three in Janamora, three in Adiarkay; and two in Telemt.

The interview was focused on the capacity of the government responsible offices to administer the ERs in general and forest resources in particular, major constraints in the management of the same, main gaps to fully discharge responsibilities, the state of coordination and synergy, and the issue of staff turnover.

To carry out the study, a semi-structured, mostly closed questions and in few cases open-ended questionnaire, which was prepared and tested before it was administered. Moreover, Focus Group Discussion (FDG) was conducted in which open ended questions were prepared and used.

To obtain the respondents, purposeful sampling was chosen for the study since the method enables to obtain accurate data and information from targeted sector ministries, bureaus, departments and offices. Targeted knowledgeable individuals were also selected and interviewed to obtain their thinking related to the study, for example, higher government officials. The purposive sampling technique is a type of non-probability sampling that is most effective when one needs to study a certain cultural domain with knowledgeable experts within (Tongco, 2007).

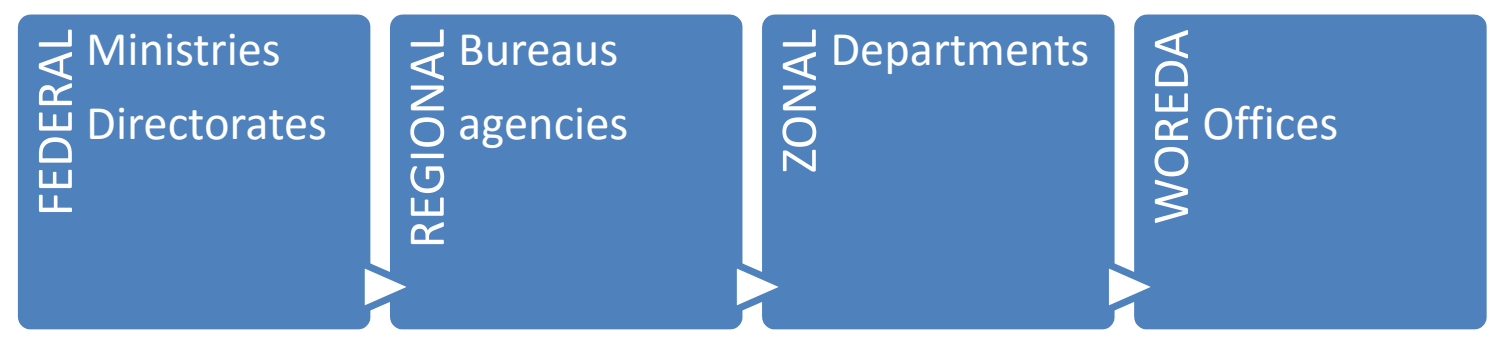

Figure 2. Governance structure of formal institutions managing ERs

At the regional levels, officials/experts in the Bureaus of Water, Irrigation and Energy and Agriculture as well as Zonal Departments of Water, Irrigation and Energy, Agriculture and Marketing Cooperation were interviewed. 
In BMER, all woredas responsible for the management of forests were included in the study. Responsible persons in sectoral offices relevant to the management of the environmental resources, namely Offices of Water, Irrigation and Energy, Offices of Land and Environment, Offices of Woreda Administration and Offices of Agriculture were requested to fill the questionnaires. In total, 40 questionnaires were completed in the 16 woredas. In addition, using more than 40 respondents of various senior experts and higher government officials were communicated through their e-mail addresses. However, 16 respondents completed and returned the questionnaires. In addition to the experts and officials, three State Ministers completed the questionnaires. All in all, 56 respondents have completed the questionnaire and returned it to the researchers.

Environmental resources conservation and management departments in Bale and West Arsi Zones were visited for intensive face-to-face interviews (FGD). Offices included were Departments of Water, Irrigation and Energy (on energy), Department of Agriculture and Department of Environmental and Land Administration, and the Oromia Forest and Wildlife Enterprise.

It was necessary to extend the study area beyond the BMER since: (i) the house of parliament is composed of elected people from the nine NRSs. And, hence, the policies and legislations approved by the house of parliament need to address Ethiopia as a whole, and (ii) the high forests in Ethiopia are mainly found in the two eco-regions, namely south-western and south-eastern Ethiopia, which are, mainly, found in the ONRS and SNNPNRS. Moreover, the Amhara National Regional State (ANRS) has unique biodiversity in and around Simien Mountains National Park, among other places. Considering theses three NRSs in this study was found necessary than focusing only on BMER alone.

At the federal level, officials in the Natural Resources Sector of the Ministry of Agriculture and Natural Resources Development, the Ministry of Environment, Forest and Climate Change, the Ethiopian Road Authority, the Ministry of Water, Irrigation and Energy were included for the interview. The zonal offices included in the study from the South-western Eco-Regions were Kafa, Shaka, Bench Maji and Illu-Ababora. North Gonder Zone in ANRS was the other zone included in the study. The woredas included in the study from the Simien Eco-Regions or North Gonder Zone were Debark, Dabat, Janamora and Adiarkay.

Moreover, experts and, in some cases, officials in some non-governmental organizations (NGOs) working in Bale, SOER and SER were interviewed with reference to challenges and major gaps in the management of environmental resources.

The concept of institution ranges from House of Parliament to single households. Households are a basic institution in every society, although the exact form differs across time and location (Doss \& Meinzen-Dick, 2015). In this study, an attempt was made to investigate institutions in relation to the formulation of policies, proclamations and regulations, strategy development and implementation of programs and projects. The House of Parliament and households were not included in the study. The reasons for not including them is because formulation of policies, proclamations, and regulations, etc. are drafted and implemented, after issued, by sector ministries and regional sector offices respectively. CBOs are important institutions', though informal' to implement projects and programmes of environmental resources nature.

\subsection{Data Analyses}

The data analyses used involved two steps. In the first step, the responses were organized under the four main research questions. The respondents that replied "Yes" were grouped under one category and those who replied "No" in another category followed by calculation of the percentiles from these responses. The second step involved the use of a two-way table of counts, which helps to organize data about two categorical variables. The two-way tables are often used to summarise large amounts of data by grouping outcomes into categories (Moore \& McCabe, 2002). Then, the Chi-square test was undertaken. The Chi-square statistics $\left(X^{2}\right)$ is a measure of how much the observed cell counts in a two-way table diverge from the expected cell counts. The following formula was used in the Chi-square test (Moore \& McCabe, 2002):

$$
x^{2}=\sum \frac{(\text { observed count-expected count })^{2}}{\text { expected count }}
$$

If the expected counts and the observed counts are very different, a large value of $X^{2}$ will result. Large value of $X^{2}$ provides evidence against the null hypothesis (Moore \& McCabe, 2002). Once the value is estimated, $X^{2}$ critical value from the Chi-square table shall be used to find a P-value. Then, conclusion about the association between the row and column variables shall be drawn. Whenever applicable, a one way Analysis of Variance (ANOVA) was conducted to assess whether the observed difference among sample means are statistically significant (Moore \& McCabe, 2002). Moreover, limited factor analysis is conducted. The goal of factor analysis 
is to find a small number of factors, or unobservable variables that explains most of the data variability and yet makes contextual sense (Suhr, n.d).

\section{Results}

\subsection{Rights and Responsibilities in the Management of Environmental Resources}

Almost all sectoral offices (100\%) responded that they have rights and responsibilities to conserve and manage environmental resources (Figure 3). More than half (55\%) of the respondents responded that they have no right to enact law while $45 \%$ of them responded that they have rights to enact laws.

Is there higher authorities to file your complaints if your rights and responsibilities are violated by another institution, organization, or individuals?

Do you have rights and responsibilities in Environmental

Resources Conservation and Management (ERCM)?

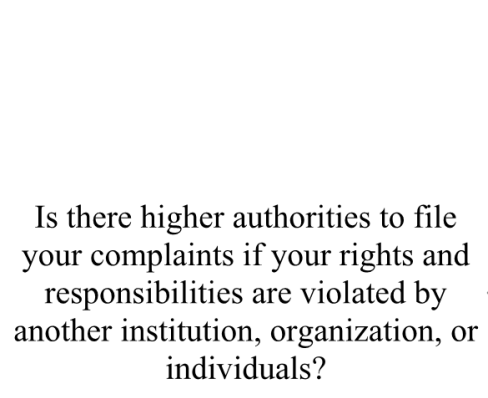

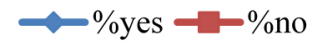

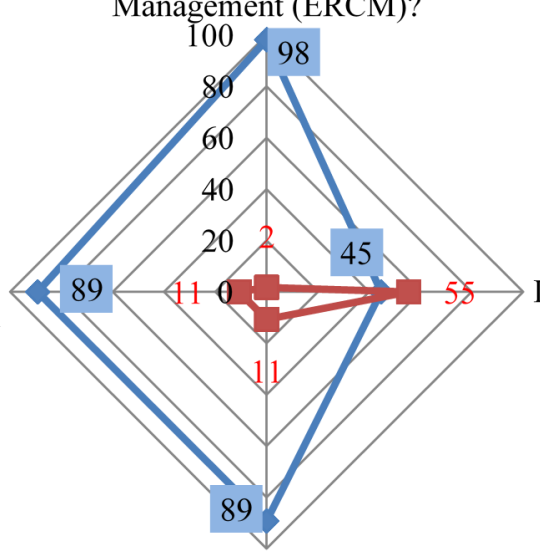

Do you have responsibilities to implement policies at the ground?

Figure 3. Rights and responsibilities of sectoral offices

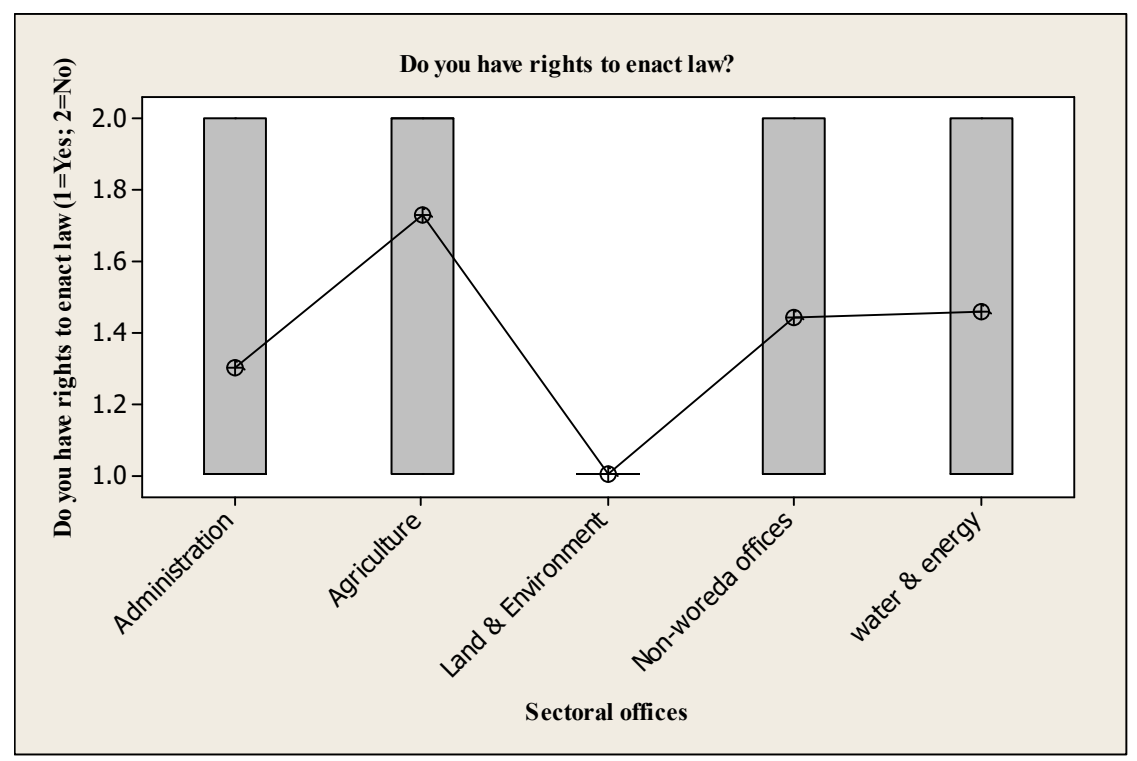

Figure 4. Rights to enact laws

Despite the average result shows proportion of respondents in favor of 'yes' is a little bit less than that of 'no', assessing the response per sectoral office was necessary to understand the full picture. The response between and within the sectors vary significantly. The response shows significant difference $\chi^{2}=34.834, \mathrm{DF}=4, \mathrm{P}<0.05$. It is obvious that the power to enact laws is vested at Federal Government. 
Explorative data analysis indicates presence of variations in the response as well (see for example Figure 4); and one-Way ANOVA test resulted statistically significant difference among sectors' response $\left[\operatorname{ANOVA}_{(4,56)}=3.29\right.$, $\mathrm{P}<0.05]$.

Feeling rights and responsibilities in the absence of power to enact laws may cause reluctance in implementation of laws given to them from the top.

Apart from that, nearly $90 \%$ of the respondents indicated that they are responsible to implement policies at the ground.

As expected, according to $80 \%$ of the respondents, the rights and responsibilities of woreda sectoral offices at the institutional level lay at woreda level. The other respondents indicated regional (10\%) and Kebele 10\%).

Most decisions are made at the top governmental structures (Figure 5). About 46, 30.4, 12.5 and 10.7\% of sectoral offices responded that decisions are made at the ministerial, state ministerial, expert and director levels, respectively. Variation within and between sectors exist which leaves the interpretation of laws, policies and responsibilities to tackle actions on their understanding.

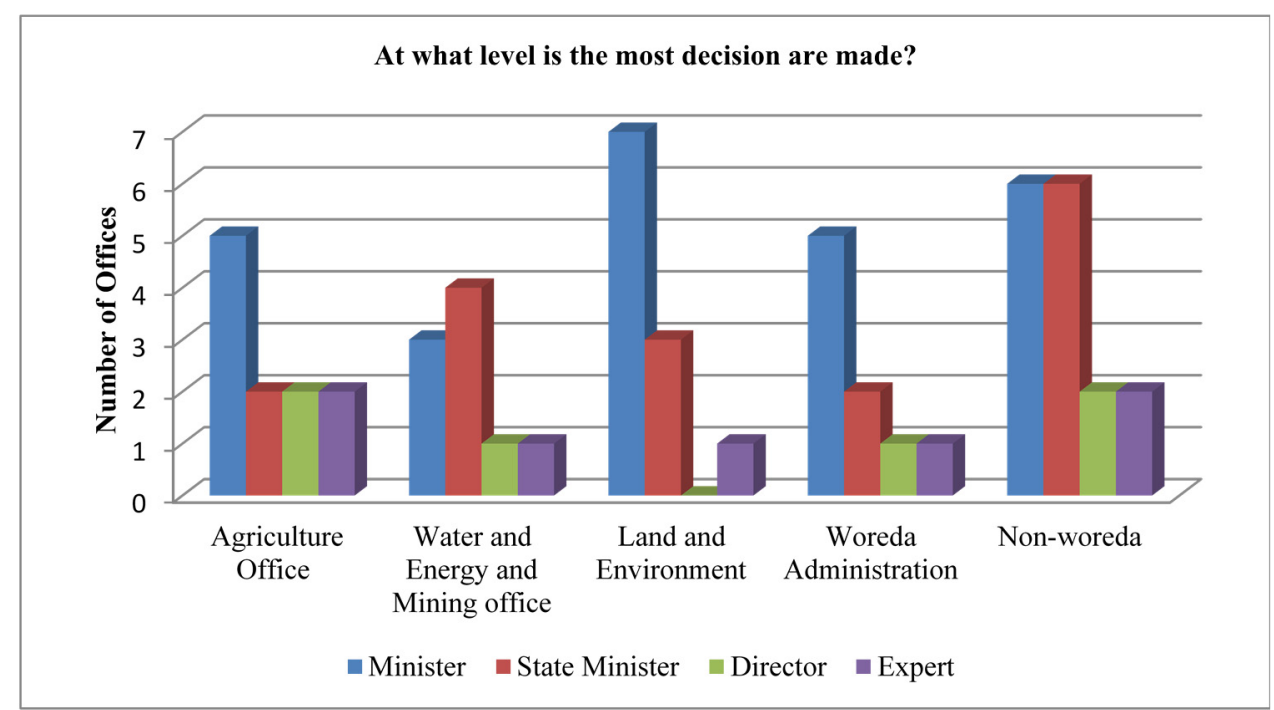

Figure 5. Levels where decisions are made

Irrespective of where or at what level the decisions are made, community rights matter most (Figure 6). About 64.3\% of sectoral offices (aggregated) responded that community rights matter most. Aggregated percentile for government, private sector and NGO rights were $21.4,10.7$ and $3.6 \%$, respectively. 


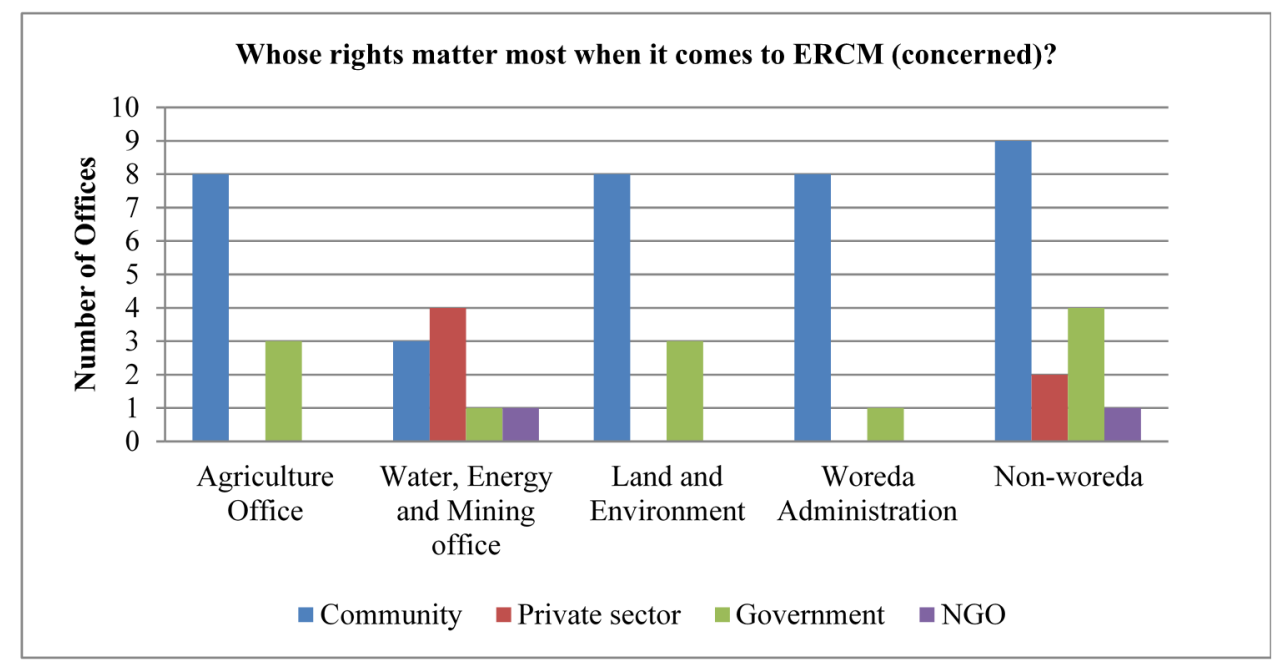

Figure 6. Whose rights matter most when it comes to ERCM?

Each sectoral office has rights and responsibilities in ERCM. They are also responsible to implement policies on the ground. However, more than half of them confirmed that they do not have rights to enact laws. Despite the fact that most decisions are made at ministerial level, community rights matter most.

\subsection{Robust Planning System Within Institutions Involved in ERCM}

About $62 \%$ of sectoral offices reflected that the existing planning and programming do not address the interests of actors in a landscape (Figure 7). The reasons might be associated with constraints, which limit the performance of sectoral plans (94\%). As a result, $84 \%$ are interested to reform the existing planning and programming setup. Sixty four percent of sectors also plan what is in their mandate irrespective of how important other sectors plan may affect them, such as road planning or mining.

During planning, sectors were asked if their sectoral offices plan in consultation with other institutions managing ERs. Though contradictory with the above result, more than $60 \%$ of all sectoral offices responded presence of consultation with other institutions during planning.

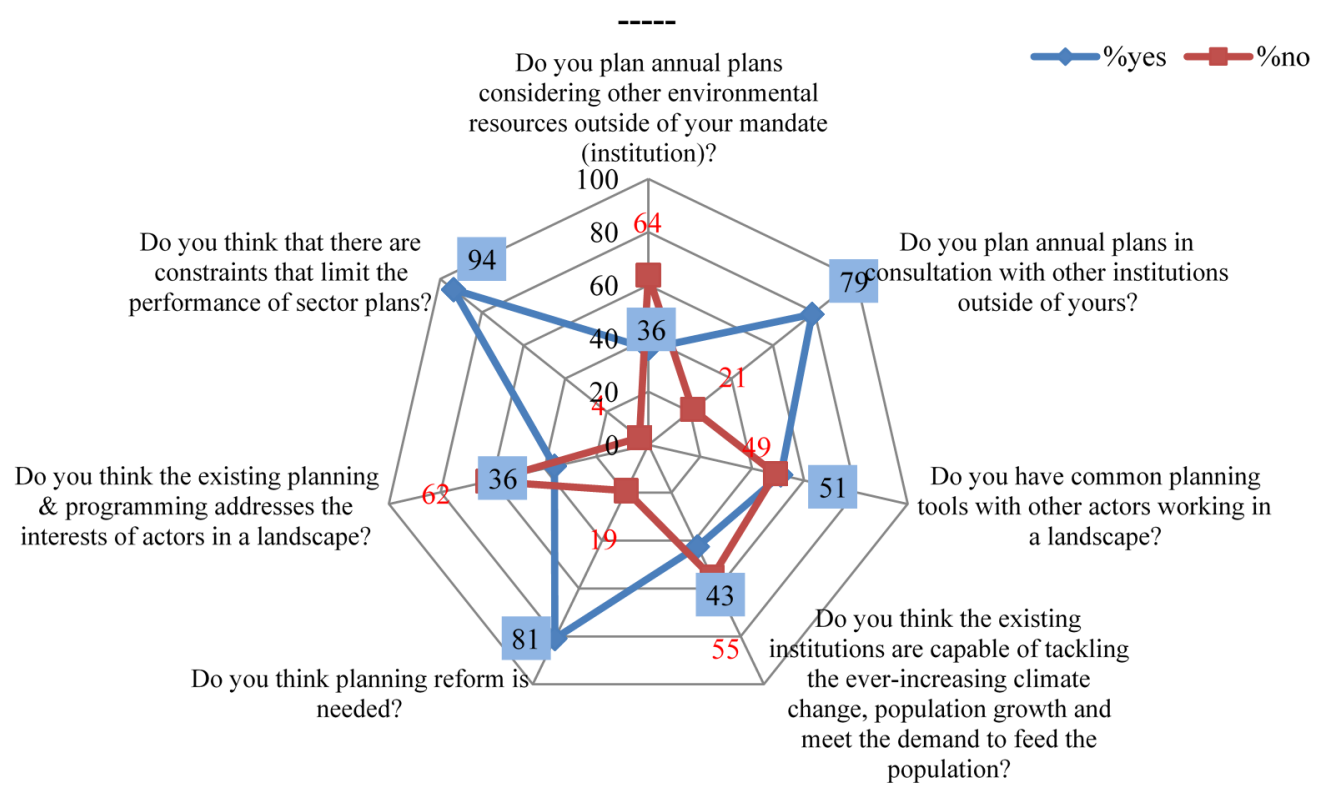

Figure 7. Responses of sectors with regard to planning 
The limiting factor to have Common Result Framework (CRF) are transaction costs $(51.8 \%)$, interest of individuals or sectoral offices (19.6\%), lack of information (12.5\%) and lack of knowledge (16.1\%). Results from Factor analysis indicates that both rotated and unrotated factors explain $89.5 \%$ of the data variability and the communality values indicate that all variables but Lack of Information are well represented by these two factors (communalities are 0.652 for Lack of Information, 0.929-1.0 for other variables).

The first factor positively loads on lack of knowledge, interest and lack of information (Fgure 8). Knowledge and information are important for planning and programming. It negatively loads on transaction cost. Therefore, one may consider factor 1 to be a "Knowledge - information" factor. The second factor might be considered to be a "Transaction cost" factor. Lack of information and interest are correlated with lack of knowledge, but not with transaction cost (Figure 8). Factor loadings represent how much a factor explains a variable in factor analysis (Minitab, 2015). Loadings can range from -1 to 1 . Loadings to -1 or 1 indicate that the factor strongly affects the variable. Loadings close to zero indicate that the factor has a weak affect in the variable. Communality is the variance in observed variables accounted for by a common factor (Suhr, n.d)

In summary, planning reform is needed to respond to wider environmental, social and economic demands of the society.

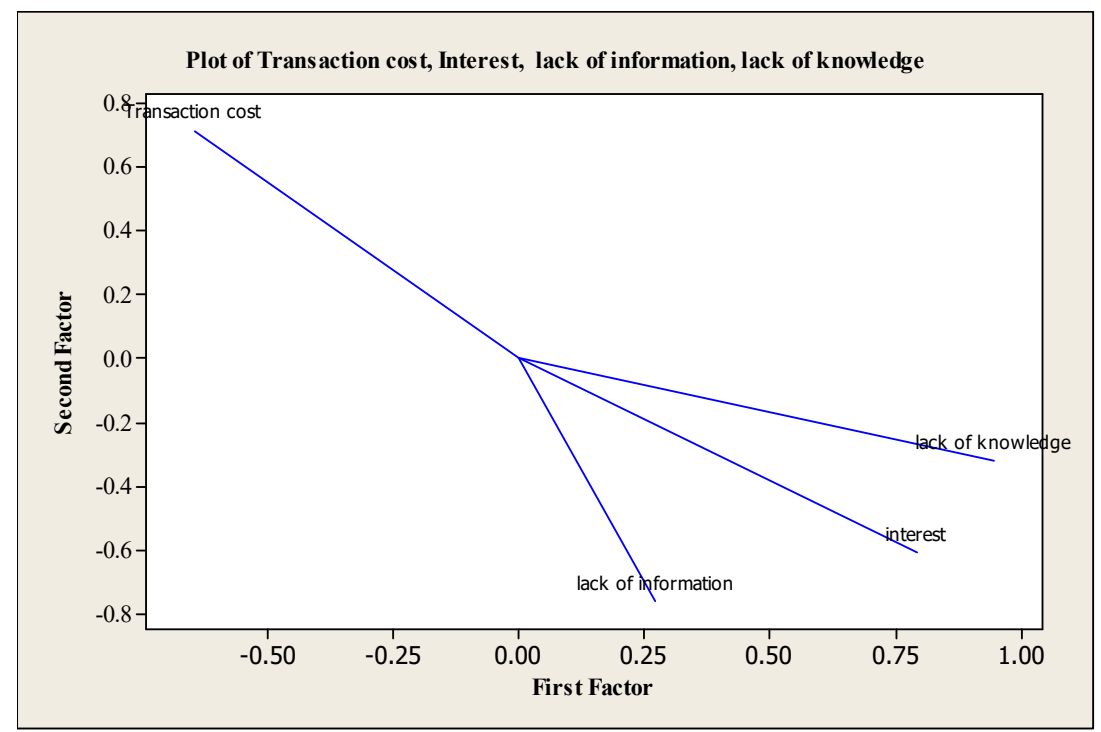

Figure 8. Factor analysis of transaction cost, interest, lack of information and lack of knowledge

\subsection{Capacity of Existing Institutions}

On average, $64 \%$ of sectoral and non-sectoral offices responded that the existing planning and programming are not satisfactory to respond to the ever increasing climate change and demands of the society (Figure 9). Accordingly, $44.4 \%$ of the Offices of Water, Energy and Mines, $54.5 \%$ of Offices of Agriculture, $90.9 \%$ of Offices of Land and Environment, $33.3 \%$ of the Woreda Administrations and $75 \%$ s of Non-Woreda sectoral offices responded that the existing planning and programming is not satisfactory $\left(\chi^{2}=91.169, \mathrm{DF}=4, \mathrm{P}<0.05\right)$. Non-woreda refers aggregated responses at federal and regional level only. 


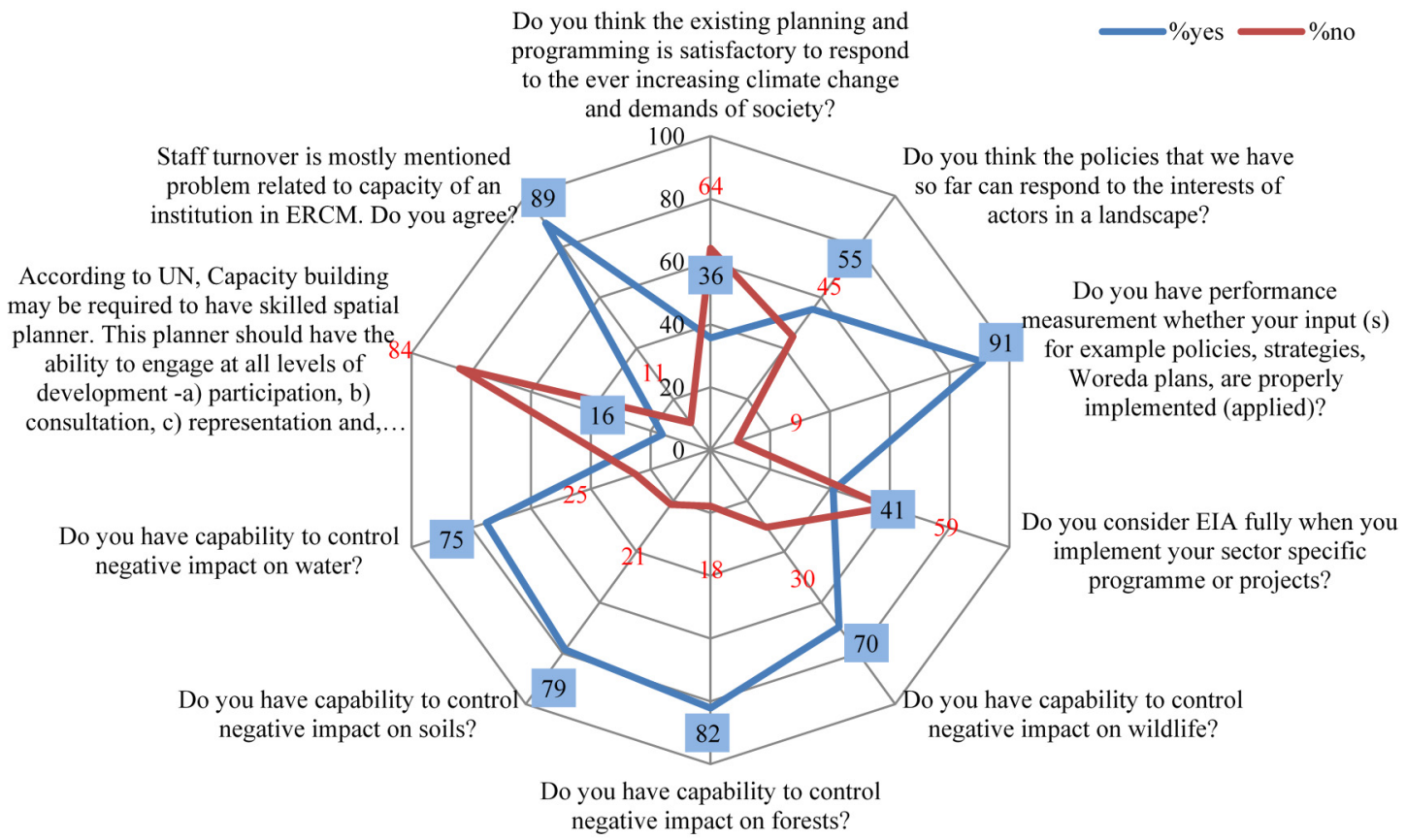

Figure 9. Capacity of sectoral offices in ERCM

Regarding policies, $82 \%$ of Offices of Agriculture and $64 \%$ of Offices of Land and Environment confirmed that the existing policies cannot respond to the interest of actors in a given landscape. But aggregated or average result shows that about $55 \%$ are convinced that the existing polices can respond to the interests of actors in a landscape. On the other hand, EIA is not fully implemented according to the majority of the sectoral offices. On average, more than $60 \%$ of all sectoral offices confirmed that EIA is not implemented fully. According to Bureau of Land and Environment of the ANRS, Government is the main violator of the EIA since Government-led mega projects are implemented without proper EIA.

Fairly high proportion of woreda sectoral offices confirmed that they have capabilities to control negative impact on natural resources (wildlife, forest, soils and water). Between 18 and $30 \%$ of sectoral offices have doubted about presence of such capabilities. More than $50 \%$ of sectoral office of non-woreda responded that they do not have capability to control the negative impact on natural resources, such as wildlife, forest, soils and water. There seems a bit of contradiction with their response since they confirmed, more or less, that most of the decisions are made at the ministerial level. On the other hand, the sectors at federal and regional levels do not have a control of negative impacts, meaning higher organs of the Government enact laws, such as legislation, without any instrument to control or monitor the implementation.

Majority of sectors (average $=48 \%$ ) agreed that the Federal Government has more power when it comes to large scale investment on land for example big dam construction and large scale agriculture development. The power that the community and regional government exercise is less. Some 31 and $21 \%$ of sectors voted for community and Regional Governments, respectively. When it comes to small scale investment in a landscape the woreda Government has more power (35\%) than communities (32\%), Regional Government (29\%) and Federal Government (4\%).

Road authority (RA) and Environmental Protection Agencies (EPA) have more power regarding road construction. Sectoral offices have identified multiple agencies that have power in road construction but it is so much scattered to arrive at any conclusion. Among the major ones that sectors made responsible for road construction are the following: Road Authority (RA) and Environmental Protection Agency (EPA) (38\%), RA and Federal Government (FG) (15\%), RA, FG and Local Government (11\%), RA and FG (11\%) and RA (10\%).

About $28 \%$ of all sectoral offices indicated that their institution is strong enough to enforce laws, such as land use policies. However, on average, more than $41.1 \%$ of all sectoral offices confirmed that their institutions are weak. 
The rest of the sectoral offices (30.4\%) stated that their offices are moderately strong $\left(\chi^{2}=194.7, \mathrm{DF}=8, \mathrm{P}<\right.$ 0.05).

Ethiopia needs spatial planner from Federal to kebele levels. Over $84 \%$ of all sectoral offices confirmed absence of such spatial planner. Moreover, staff turnover is one of the limiting factors for institutional capacity to operate sufficiently. More than $90 \%$ of all sectors confirmed that staff turnover is indeed a problem. However, $25 \%$ of non-woreda sectors did not see staff turnover as a problem. Some politicians see it as healthy phenomena and measure it against the opportunities that the Government has created, through a conducive policy, for experts to choose from.

Regarding salary versus result-based payment, more than $37 \%$ of all sectoral offices agreed that paying [just] salary makes experts lazy. More than $44 \%$ are not sure and responded simply "may be". However, more than $81 \%$ of all sectoral offices agreed that better payment for results achieved is the way forward for effective individual performance. Aggregated result shows that some $16.7 \%$ are not sure whether payment for result would be better and they stated "may be". The one way ANOVA analysis indicate presence of statistical significant difference $\left[\operatorname{ANOVA}_{(2,14)}=56.58, \mathrm{P}=0.000\right]$.

Both unrotated and rotated factors explain $47.5 \%$ of the data and the communality values indicate that one variable, yes, is well represented except the two variables, no and maybe (communalities are 1.00 for yes, $0.099-0.325$ for the other two). The first factor (Figure 10) positively loads on no, may be and yes, but more on yes and maybe. The importance of better payment for performance is very well correlated with factor 1 . The second factor disagrees with better payment, meaning, there may be other factors to improve result but not necessarily better payment.

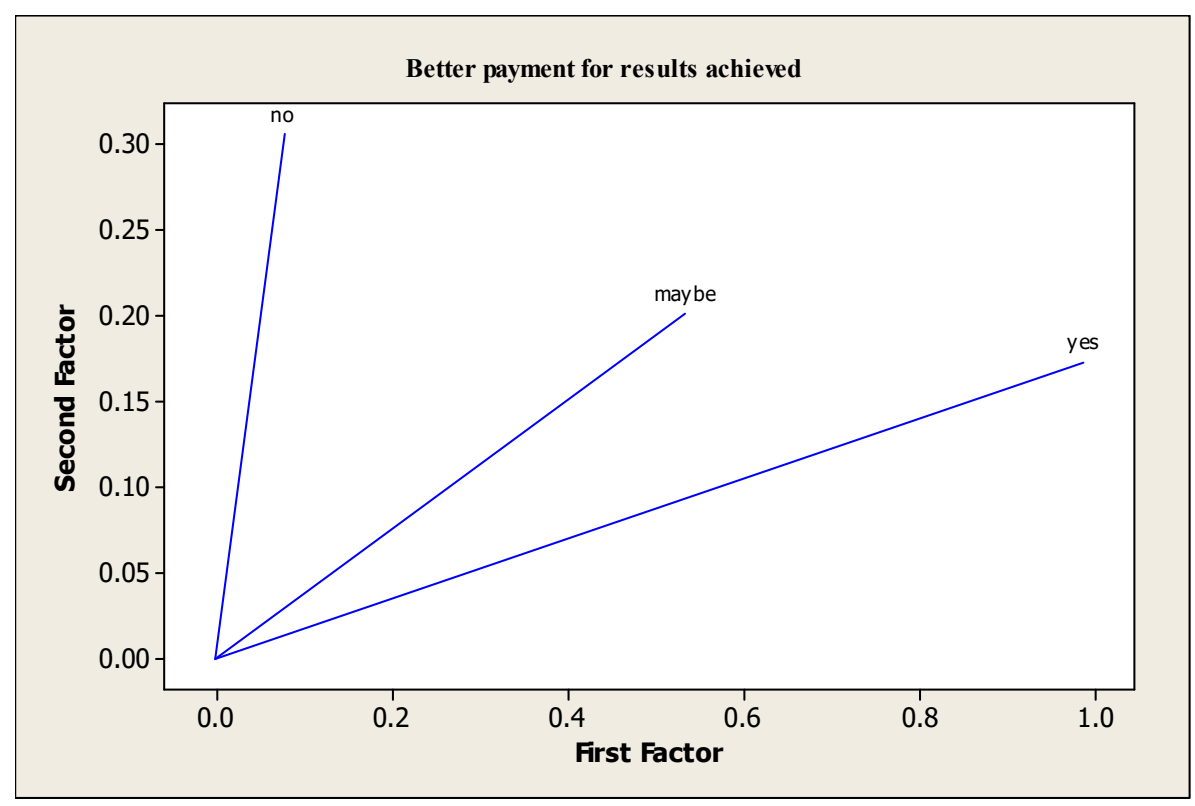

Figure 10. Do you think better payment for results achieved would improve deliverables in any organization?

\subsection{Motivations of Community-Based Organizations}

On average $90 \%$ of sectoral offices agree that incentive is important to motivate CBOs to discharge their responsibilities effectively $\left(\chi^{2}=19.048, \mathrm{DF}=4, \mathrm{P}<0.05\right)$ (Figure 11). 


\section{What motivates CBOs to discharge their responsibilities effectively?}

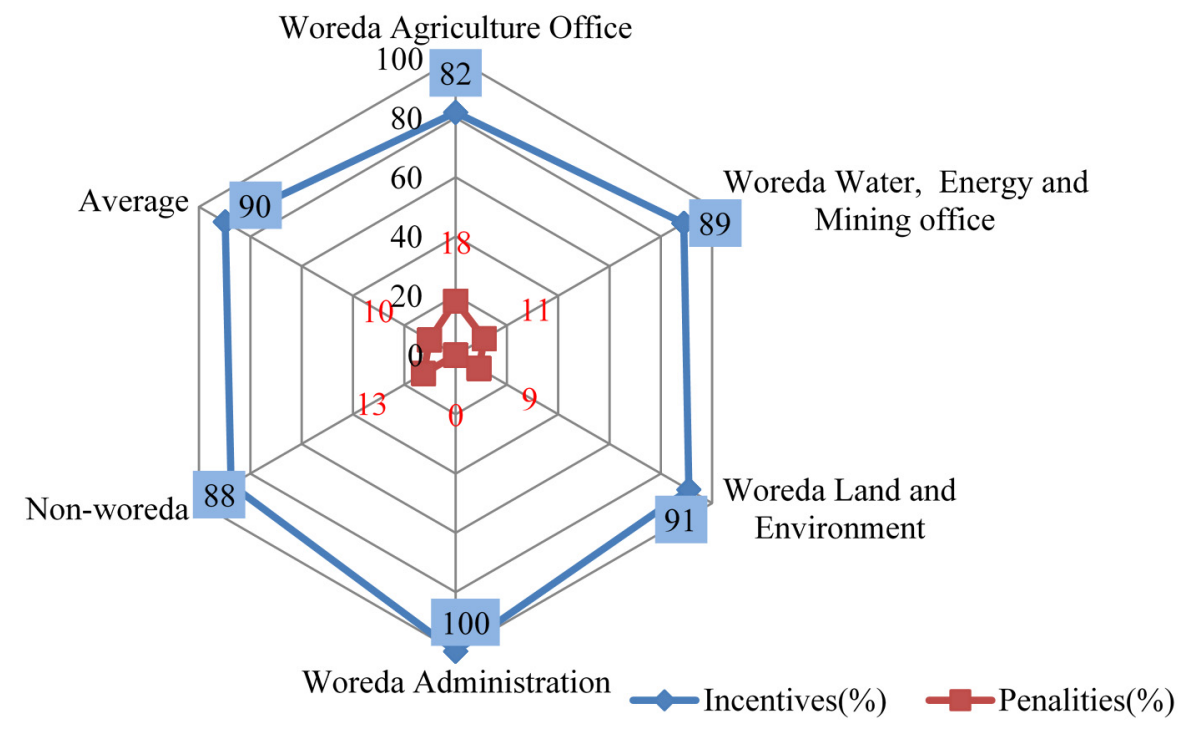

Figure 11. Motivation of CBOs to discharge their responsibilities effectively

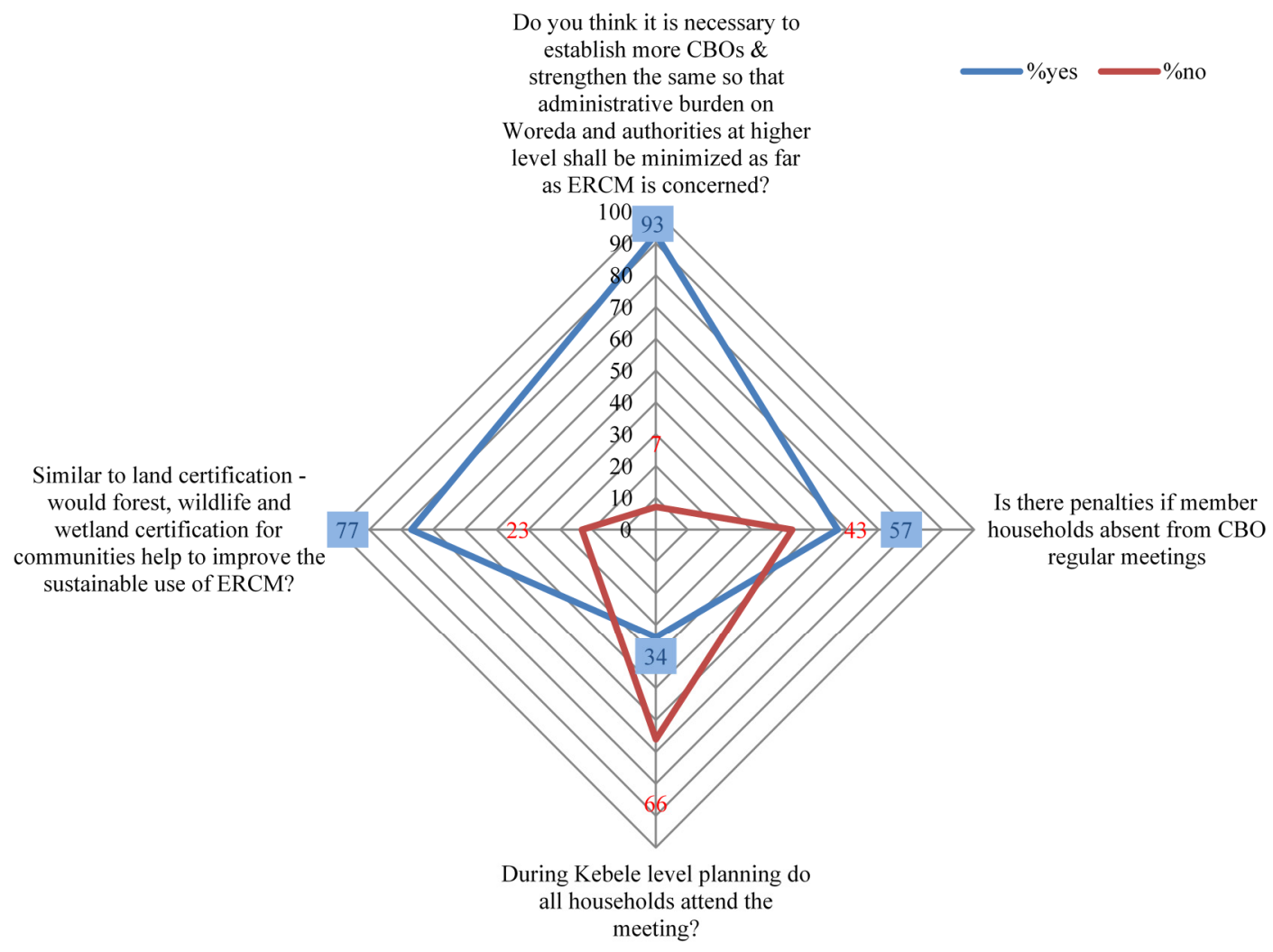

Figure 12. Planning, certification and $\mathrm{CBOs}$

Less than $35 \%$ of sectoral offices responded that all CBO members are attending meetings during keble level planning. Majority of sectoral offices (more than 60\%) responded that CBO members do not necessarily attend such meetings (Figure 12). More than $40 \%$ confirmed that there is no disciplinary measures when a member is 
absent from such planning meetings. However, $57 \%$ of the sectoral offices confirmed presence of some sort of penalty

$$
\left(\chi^{2}=95.250, \mathrm{DF}=4, \mathrm{P}<0.05\right) .
$$

As far as incentives are available, CBOs are effective in ER management. Hence, establishment and strengthening of more CBOs is stated as important by more than $93 \%$ of all sectoral offices. From all sectors, more than $78 \%$ agreed that forest certification to CBOs is as important as land certification to improve tenure or ownership issues and in a way can be considered as incentive to them (Figure 12).

The responses regarding the frequency of consultation of the communities regarding projects and programs that have an effect on the environment were once (3.6\% of sectoral offices), many times ( $46.4 \%$ of sectoral offices) to as deemed necessary (37.5\% of sectoral offices).

\subsection{Focus Group Discussion (FGD)}

Land use policy and forestry stood out as the two under-funded thematic sectors in all visited zones. Sectoral Departments of Environmental Protection and Land Administration agreed that land use and land administration must be given due attention to lead and guide implementation of landscape-related projects and programmes. However, it is lacking. Strong institution to lead the implementation of the land use policy and to control negative impact on natural resources, including forest resources, is required. Absence of proper land use plan allows livestock to graze in the national parks and biodiversity sensitive frosts. Cultivation of steep slopes against the Land Use Land Administration Proclamation of the country is a common practice in most visited zones.

The capacity to control encroachments and illegal settlements in forest and wildlife protection areas is minimal. Forest user groups are established to manage forest resources with government under Participatory Forest Management (PFM). The CBOs are given the challenging tasks to control those difficult tasks, such as illegal settlement and other encroachments. But the support they get from legal departments for law enforcement is constrained by either lack of quick response or corruption. Most of the time law enforcement is conducted in coordination with all relevant offices (or taskforces), such as police, which is a sometimes a challenge because of parallel assignments for some of the task force members assigned. This limits involvement of the task force members and makes the exercise incomplete. Additional constraints for weak law enforcement include favoritism, clan related issues, corruption, and intermarriage arrangements.

Among incentives that the CBOs derive from forest are the Non-Timber Forest Products (NTFPs). Honey, wax and coffee are major NTFPs. The capacity of the CBOs to produce quality products for international market has a big constraint. For example, the moisture content of honey should be less than $20 \%$ in the European Market. But, most of the honey produced in SOER is $20 \%$ and above. Member of the CBOs use traditional beehives because of financial limitations to purchase modern beehives, which could improve the moisture content. Spices and condiments have huge potential, but they are not well developed.

In the SOER, problems associated with agriculture investment are severe. Local community or CBOs and local sectoral offices failed to stop the companies investing on coffee and tea businesses by destroying the forest resources as well as associated social and natural environment. Land areas covering over 5,000 ha for agricultural investments are assigned by the Federal Government. Land areas that cover less than 5,000 ha are allocated to investors by the Regional Investment Bureaus. The capacity of Local Government and local sectoral offices is weak or incapable to stop the undesirable agricultural investment initiatives.

The three Biosphere Reserves (BRs) in the SOER were expected to have a management entity that can coordinate and make collaboration within and between different sectors, which has not, as yet, materialized. The zonal offices still see the management of biospheres as being the responsibility of NGOs. As a result of this misconception, various investment proposals are planned within the BRs. According to one office, about nine investment projects which are not compatible with UNESCO BR principles are planned in and around one of the three BRs.

The capacity of PFM user groups to control negative impact from agriculture investment, illegal settlement and other negative impacts is not strong yet. The incentives, benefit sharing architecture, discharge of roles and responsibilities are not clarified yet. Despite the fact that bylaws exist, they are not strong enough to become effective and efficient.

All respondents confirmed that there are big gaps of, amongst others, technical and financial capacity of their institution and staff turnover is high. Material and tools necessary for implementation of annual plans, such as vehicles, motor bicycles, nursery tools to raise seedlings, instrument for surveying and forest measurement are lacking in all visited zones and woredas. 
Apart from some capital budget funded programmes, such as Sustainable Land Management, there is no systematic coordination mechanism for regular programmes. Sectors offices submit their plans, which are approved by the relevant bodies depending on the availability of funds. Inter-sectoral planning is lacking. Woreda government-led annual plans are examined by woreda Cabinet. The Woreda Cabinet determines the fund allocation, and for sectors categorized as less priority by the local government, e.g. forest and alternative energy sectors, insufficient budget is allocated.

The effect of synergetic approach in ERCM is not yet obvious. From the FGD it was learnt that watershed development plans are prepared by the land and Environment Protection Office, but implemented by the Office of Agriculture. During the development of the watershed plan, there is little involvement of the Office of Agriculture.

Different interest groups exist, namely UNESCO Heritage Sites promoting group versus PFM group in BMER and SER and UNESCO BR and PFM in SOER. In BMER and SER, experts prefer to see parks without interference of people. FARM Africa, SOS Sahel, and other NGOs are advocating for participatory resources management of wild animals and forest resources.

\section{Discussion}

\subsection{Rights and Responsibilities in the Management of Environmental Resources}

Sectoral offices confirmed that they have rights and responsibilities in ERCM. They are also responsible to implement policies. However, more than half of them stated that they donot have rights to enact laws. The power to enact laws in connection with ERCM, historical sites and objects is vested in the Federal Government. Member States of the Federal Democratic Republic of Ethiopia (FDRE) only have the power to administer land and other natural resources in accordance with federal laws (FDRE, 1995). Thus, it is not clear how some of the respondents came to claim as having the power to enact laws and policies. In an ideal situation, the right to manage ERCM should include the right to make decisions in favor of ecological/environmental, social as well as economic benefits irrespective of where the sectoral office is situated, be it federal, regional or woreda.

Although the sectoral offices confirmed that they have rights and responsibilities: (a) their decision power is controlled by higher authorities who have weak capacity to influence (Mekonnen \& Bluffstone, 2015) b) sectors at woreda level cannot enact any sort of laws and (c) their capacity is constrained by frequent changes in institutional arrangements, poor staffing and limited funding, amongst others (Mekonnen and Bluffstone, 2015).

These results showed that community rights matter most, but decisions (policies, legislations and regulations) affecting these rights are being made at ministerial level. Although giving recognition to community rights is important, unless it is accompanied with conducive environment to exercise them creates a kind of one-step 'forward' and two steps 'backward' situation. The instruments available to ensure community rights are vague. In some areas, owners of ER such as farmland and communal lands have a legal document (land certificate) issued by the government which exhibits their ownership rights. However, there are no such legal documents for forests, forest lands and wetlands. One of the mechanisms could be revisiting the property rights systems in the country. Property right affect the incentives and structure for collective action at both the community and household level (Doss and Meinzen-Dick, 2015). For example, Natura 2000 is a network of core breeding and resting sites for rare and threatened species found within Europe's 28 member states. It is not entirely nature reserve without people rather most of the land is privately owned (European Commission, 2016).

Recognizable variations are observed in the responses within and between sectors regarding rights and responsibilities, which may indicate that the capacity of sectors to understand and interpret the existing policies, laws and decision mechanisms, and implement them on the ground is limited. Failure to understand the existing policies, including the Federal Constitution, and decision mechanisms in unison can create delay and confusion in the implementation modalities.

\subsection{Robust Planning System Within Institutions Involved in ERCM}

Planning reform is needed to respond to the wider environmental, social and economic demands of the society. These results show that the existing planning and programming does not address the interests of actors in a landscape. These reasons might be associated with constraints, which limit the performance of sector plans. According to the respondents, the constraints are skilled manpower limitation, poor planning, inappropriate institutional arrangements, lack of sufficient materials and finance, weak monitoring and evaluation system employed, poor leadership, and 'thinking inside the box'. "The more complex the institutional order, the deeper the division of labor, the less one single person can 'see' or 'know' the whole picture. In these circumstances, all decision-making could be subject to error (Aligica and Boettke, 2009). But, working in partnership with other sectors to ensure sustainable development at the local level can be rewarding. Such coordination helps to avoid 
land use conflicts in a landscape (Nune, 2011). Additionally, the actions proposed to be taken are based on wider environmental perspectives rather than being sector specific, hence, errors can be minimized or easily adjusted (Aligica and Boettke, 2009).

Unfortunately, the existing system does not require cooperation among various sectors during planning and programming or to exchange information and knowledge apart from implementing what is written for their respective mandates. Each sector would like to maximize its outcome; for example the Agriculture sector always puts emphasis on how to increase production area and productivity irrespective of other environmental and social costs. They are afraid that they may fail to meet the production quota set by the government if they are to cooperate and form a common planning tool or result framework with other relevant sectors. Such reluctance is a result of fear that the sectors concerned with the environment, such as forestry and environmental protection agencies, may resist deforestation for agriculture expansion, use of commercial fertilizers, pesticides or herbicides altogether. Therefore, rather than cooperation such sectors prefer defection (Taylor, 1987).

Moreover, there is no sanction imposed on those who are focusing only on their institutional annual plans. Conversely, there is no mechanism or incentive for sectors that wish to cooperate with other sectors during planning. Government or the public at large can put coercive measures or incentives in place so that sectors can develop robust planning system for ERCM. For example, disregarding the possibility of human rights violation in the process, China used coercive measures to control its population growth (Hardin, 2007).

Limited consultation in a landscape takes place before any plans are endorsed. The plans may not satisfy the needs of actors as these actors have different interests and needs, leading to sub-optimal and sometimes unethical outcomes (Sayer et al., 2013). The emerging stressors of climate change require integrated interventions that link plot-level decisions with larger planning frameworks-value chain development and landscape-level management (Simpson and Burpee, 2014). Thus, integrated spatial approach requires reform in planning.

Transaction costs, interest, information, and knowledge are cited as limiting factors to have common result framework in ERM. Transaction cost in this research refers to costs associated with executing activities outside of 'mandates' specified by higher authorities of each sector offices. The interpretation of the results from this research is that the cost of planning together has to be less than the profit that individual sector offices gain, though there is no evidence whether or not the cost of transaction is higher. Because, in planning and coordinating of ERCM the expected outcome is always greater than the sum: $1+1+1>3$.

In this research, despite the fact that transaction cost emerged as the highest response compared with others, FGD showed that interest of an organization or an institution can determine the type of intervention in ERCM. The BR and PFM groups in the SOER approach ERCM institutions in a competitive manner, i.e. in a negative way. Both $\mathrm{BR}$ and PFM concepts are relevant, but due to lack of interest to work together, one can witness unnecessary confusion between and among institutions, which is counterproductive.

The role of proper information and knowledge that individuals within an institution have about common result framework is also acknowledged by the respondents. It is necessary that institutions should be sufficiently ready to accommodate future uncertainties posed by, for example, climate change. Therefore, having common result framework for ERCM can enhance the flow of information and new knowledge to respective sectors. According to Aligica and Boettke (2009), new knowledge gives rise to new possibilities. Information, knowledge, communication and coordination are some of the building blocks of the emerging vision of social order.

\subsection{Capacity of Existing Institutions}

Institutions are responses or solutions to generic challenges or 'threats'. Understanding the nature of the 'threats' operating at different levels offers clues for understanding the institutional arrangements emerging as a response to them (Aligica and Boettke, 2009). Challenges at the grass root level are different from challenges at higher levels: Federal government being the highest decision making body while Kebeles are the lowest administrative units (Figure 13). 


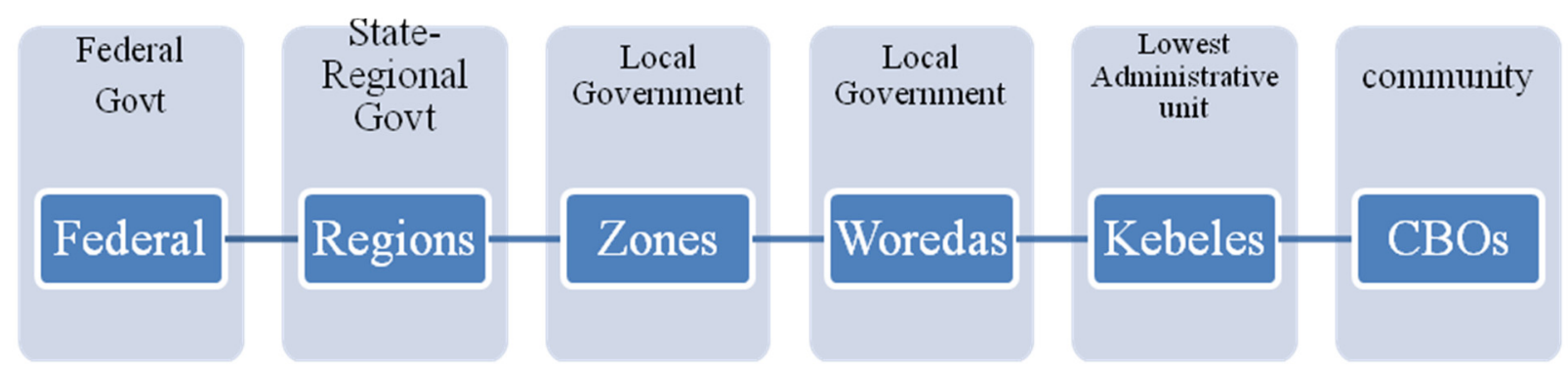

Figure 13. Institutional arrangement schema $($ Govt $=$ Government $)$

Our findings indicate that the existing policies are not perfect or satisfactory to respond to the interest of actors in a landscape even though some sectors feel otherwise. Policies are issued at the Federal level. Sectoral ministries and their mandates are also determined at Federal level. Even though EIA is mandatory to practice in most ERCM sectors addressed in this research, implementation is subject to the governments' willingness at both federal and national regional levels, especially when it comes to government-related projects and programs (Fante, 2015). Having legal instruments and policies is one thing, but they are of no use if not implemented. It is better to realize that "one can never do merely one thing" as every action has its own consequences; hence public policies must primarily be concerned with consequences (Hardin, 2001).

Moreover, the results revealed that staff turnover is one of the limiting factors for institutional capacity to operate sufficiently. High staff turnover, amongst others, is a real concern in common environmental resources management, for example, forests in Ethiopia (Mekonnen and Bluffstone, 2015). Mostly, reasons for staff turnover are search for better payment and career development.

Most ER-related decisions are made at the higher level (Ministerial and State Ministerial levels). Also, such power is vested in higher authorities including road sector regarding infrastructure development and large scale agriculture investments. This is operated in the absence of spatial planners in landscapes or absence of land use plan at all. The decisions and plans made at the higher level lack the knowledge of the spatial planning categories and their context. But, to effect landscape level challenges in natural resources management, providers of extension and advisory services have to work with and through multi-stakeholder decision processes, help broker agreements, strengthen management structures and mediate conflicts (Simpson and Burpee, 2014).

Ethiopia needs spatial planners from federal to kebele levels. To implement spatial planning, the development of relevant laws, policies, guidelines, procedures and incentives call for attention (United Nations, 2008). Legislations that are relevant for the landscape approach are required. Those that are not relevant should not be left to hamper the process. European commission has over 200 legal acts to monitor the 27 member states on their performance in environmental fields (European Commission, 2016). The legislative measures cover all environmental sectors, including water, air, nature, waste, noise, and chemicals, and others which deal with cross-cutting issues such as environmental impact assessment, access to environmental information, public participation in environmental decision-making and liability for environmental damage. Capacity building may be required to have skilled spatial planner. These planners should have the ability to engage at all levels of development, i.e. (a) participation, (b) consultation, (c) representation and (d) appeal (United Nations, 2008). Also, planners in a landscape need to consider having strong networks to mobilize others or the ability to speak eloquently whenever there are decisions by consensus in an open meeting (Doss \& Meinzen-Dick, 2015).

If large scale investments and infrastructure development initiatives, e.g. roads, are orchestrated by the Federal Government, the capability of sector offices to control the negative impacts on forests, wildlife, water and other natural resources seems unrealistic. The current practice shows that land is being used the way it suits the user(s). Steep Mountain tops are under cultivation. National Parks are serving as grazing land for livestock (e.g., BMNP). Hence, the cost of environmental damage is probably already high. If Ethiopia continues "business as usual", more productive areas may be turned into food insecure zones. In Europe, the costs of not implementing current legislation are broadly estimated at around $€ 50$ billion a year in health costs and direct costs to the environment (European Commission, 2016).

Maintaining experienced staff through provision of required skill, education and improving working environment, including benefits for results achieved is an important step to improve capacity of the institution or any institution. The research revealed that knowledge and skill to identify and analyze current and future challenges of ERCM is limited, if not lacking in most cases. For example, technologies applicable to a specific geographic area are being 
applied wrongly to different agro ecology and socio-economic situations. Therefore, maintaining or recruiting professionals who have capacity to cope with the current and future challenges is required since the ability to cope with the future is a necessary condition for any institutional design (Aligica and Boettke, 2009).

\subsection{Motivations of Community-Based Organizations}

CBOs are grass root institutions responsible for ERCM. Their performance is determined by a number of factors, both internal and external. Active participation of members and having quality leadership make or break the CBOs. During the FGD, it was clear that law enforcement is very much dependent of the performance of law enforcement committee as well as the good collaboration of the justice and police departments, amongst others. Among challenges CBOs face today, delay in decision making by the courts and corruption are worth noting.

Participation is a function of incentives. CBOs motivate well provided that incentive is available and the external support to enforce the law is conducive and predictable. Incentives can range from food aid in areas of food insecure woredas for community based area exclosures (Mengistu et al., 2005), lower taxes on revenues to protection of rights (Leite et al., 2014; Doss and Meinzen-Dick, 2015). It is presumed that when someone does not own a resource, one has no long-term interest in sustaining the resource over time and, thus, cannot be expected to act beneficially towards that resource (Ostrom and Cox, 2010).

Incentives should be seen quickly. The longer the time it takes to enjoy the benefits/incentives from any kind of investment, the more it makes collective action problematic (Doss \& Meinzen-Dick, 2015). Among incentives for CBOs recognition of their rights, responsibilities and power, facilitating various means, such as property rights (communally) through certification, and increasing their capacity to manage and monitor ER, and defending their rights are very crucial.

Cognizant of the fact that CBOs are key institutions at the grass root level, there was unanimous agreement on the establishment of more CBOs wherever they are required. Forest certification to CBOs is as important as land certification to improve tenure or ownership rights and, in a way, can be considered as incentive to them. It is very important to keep in mind that insecurity of tenure can undermine collective action (Doss \& Meinzen-Dick, 2015).

\section{Conclusions}

Forest loss between 2000 and 2013 in Ethiopia exceeded one million hectares, the highest loss being in Combretum-Terminalia forests followed by moist Afromontane and Acacia - Commiphora forests (MEFCC, 2016). According to MEFCC (2016), between 25 and 30\% of the deforested land is occupied by agriculture and equivalent amount of forest land is converted to grazing land. The knock-on effect of the deforestation has adverse effect on other environmental resources, such as water and biodiversity; and also on rural livelihoods whose livelihood depends on Non-Timber Forest Products (Nune, Soromessa, \& Teketay, 2015). This could be a manifestation of the discussions made above that the rights and responsibilities are not clear, policies are imperfect or weak, there is no robust planning and programming system, capacities of sectoral offices at the lower levels are extremely weak, and community property right situation is unclear. In general, the institutional arrangements required for effective implementation of REDD + and management of environmental resources need critical review and analyses so that it is possible to design responsible institutions for ERCM at all levels. This includes availing knowledgeable and all rounded professionals at all levels, with proper incentive mechanisms, who could be able to cope with future challenges emanating from climate change, and other social tensions. ERCM deserves at least professionals who think 'outside the box'. From this study it could be concluded that planning reform has to be the main component of the institutional design.

\section{Acknowledgements}

The authors would like to acknowledge the Royal Norwegian Embassy in Addis Ababa for the financial support provided during the research period.

\section{Reference}

Aalbaek, A. (1993). Tree Seed Zones for Ethiopia. Humlebaek, Denmark: Danida Forest Seed Centre.

Aligica, P. D., \& Boettke, P. J. (2009). Knowledge and institutions: Devloping a social philosophy of institutional order and chnage. In P. D. Aligica, \& P. J. Boettke (Eds.), Challenging Institutional Analysis and Development (pp. 55-75). London and New York: Routledge; Taylor and Francis Group .

Aligica, P. D., \& Boettke, P. J. (2009). postscript:Rethinking Institutional Analysis and developmemt. Dialogues with Vincent and Elinor Ostrom. In P. D. Aligica, \& P. J. Boetkke (Eds.), Chhallenging Institutional Analysis and Development (pp. 142-159). 
Boliari, N., \& Topyan, K. (2007). Conceptualizing Institutionas and Organisations: A Critical Approach. Journal of Business and Economics Research, 10.

Central Statistics Agency [CSA]. (2013). Population Projection of Ethiopia for all Regions at Wereda Level from 2014-2017. Addis Ababa: CSA.

CSA. (2015). Key indicators. Retrieved November 26, 2015, from CountrySTAT Ethiopia: http://www.countrystat.org/home.aspx?c=ETH

Doss, C. R., \& Meinzen-Dick, R. (2015). Collective Action within the Household: Insights from Natural Resources Managment. Elsevier, 171-183.

Ministry of Natural Resources Development and Environmental Protection [MoNRDEP]. (1994). Ethiopian Forestry Action Program: Volume III-Issues and Actions. Addis Ababa: MoA.

European Commission. (2016, January 13). Natura 2000. Retrieved Febraury 20, 2016, from http://ec.europa.eu/environment/nature/natura2000/index_en.htm

Fante, M. (2015, October 20). Impacts of Institutional Arrangements on the effective Implementation of REED+ and Management of Environmental Resources in Ethiopia. (S. Nune, Interviewer)

FAO. (2009). How to feed the world in 2050. Rome: FAO. Retrieved November 22, 2015, from http://www.fao.org/fileadmin/templates/wsfs/docs/Issues_papers/HLEF2050_Global_Agriculture.pdf

Federal Democratic Republic of Ethiopia [FDRE]. (2015). Climate Resilient Green Economy: National Capacity Development Program Gap Assessment and Findings. Addis Ababa: MoFEC.

FDRE. (1995). Constitution of the Federal Democratic Republic of Ethiopia. Proclamation No. 1. Addis Ababa: Berhanena Selam Printing Press.

Friis, I., Demissew, S., \& van Breugel, P. (2011). Atlas of the Potential Vegetation of Ethiopia. Addis Ababa: Addis Ababa University Press \& Shama Books.

Geist, H. J., \& Lambin, E. F. (2001). What Drives Tropical Deforestation? A meta-analysis of proximate and underlying causes of deforestation based on subnational case study evidence. Louvain-la-Neuve: LUCC International Office.

Hardin, G. (2001). Carrying Capacity as an Ethical Concept. Retrieved Janury 4, 2016, from Garetthardinsociety: http://www.garretthardinsociety.org/articles/pdf

Hardin, G. (2007). The Tragedy of the Commons. Jastore, Science, New Series, Vol. 162, No. 3859. (Dec. 13, 1968), pp. 1243-1248. Retrieved 12 25, 2013, from http://cecs.wright.edu/ swang/cs409/Hardin.pdf

IPCC. (2015). Climate Change 2014. Geneva: Intergovernmental Panel on Climate Change.

Keizer, P. (2008). The Concept of Institution: Context and Meaning. Utrecht: Utrecht University School of Economics .

Kindu, M., Schneider, T., Teketay, D., \& Knoke, T. (2015). Drivers of landuse/landcover chnage in Munessa-Shashemene landscape of south-central highlands of Ethiopia. Environmental Monitoring and Assessment, 187, 1-17. http://dx.doi.org/10.1007/s10661-015-4671-7

Mekonnen, A., \& Bluffstone, R. A. (2015). Forest Tenure reform in Ethiopia. In R. A. Bluffstone, \& E. J. Robinson (Eds.), Forest Tenure Reform in Asia and Africa: Local Control for Improved Livelihoods, Forest Managment, and Carbon Sequestration (pp. 56-73). New York: Taylor \& Francis; Routledge.

Mengistu, T., Teketay, D., Hulten, H., \& Yemeshaw, Y. (2005). The Role of Communities in Closed Area Managment in Ethiopia. Mountain Research and Development , 44-50.

Ministry of Environment, Forest and Climate Change [MEFCC]. (2016). Ethiopia's Forest Reference Level Submission to the UNFCCC. Addis Ababa: MEFCC.

Ministry of Finance and Economic Development [MoFED]. (2010). Growth and Transformation Plan (GTP) 2010/11-2014/15. Addis Ababa: MoFED.

Minitab. (2015). Minitab Inc. Retrieved from http://support.minitab.com/en-us/minitab/17/topic-library/ modeling-statistics/multivariate/principal-components-and-factor-analysis/what-are-factor-loadings/

Moore, D. S., \& McCabe, G. P. (2002). Introduction to the Practice of Statistics. New York: W.H. Freeman and Company. 
Nune, S., Soromessa, T., \& Teketay, D. (2015). Non-carbon benefits for effective implementation of REDD+: The case of Bale Mountains Eco-Region, Southeastrn Ethiopian. African Journal of Environmental Science and Technology, 9(10), 747-764. http://dx.doi.org/10.5897/AJEST2015.1953

Ostrom, E. (2007). A diagnostic approach for going beyond Panaceas. PNAS, 104(39), 7. Retrieved April 20, 2015. http://dx.doi.org/10.1073/pnas.0702288104

Ostrom, E., \& Cox, M. (2010). Moving Beyond panaceas: a multi-tiered diagnostic approach for social-ecological analysis. Environmental Conservation, 13. http://dx.doi.org/10.1017/s0376892910000834

Sayer, J., Sunderland, T., Ghazoul, J., Pfund, J.-L., Shell, D., Meijaard, E., . . Buck, L. E. (2013, May). Ten Principles for landscape approach to reconciling agriculture, conservation, and other competing land uses. PNAS, 110(21), 8. http://dx.doi.org/10.1073/pnas.1210595110

Sherefa, B. (2007). Landuse/Landcover chnages in Andracha and Masha Woredas of Sheka Zones, SNNP Regional State. In M. Fetene (Ed.), Forests of Sheka (pp. 21-56). Addis Ababa: MELCA Mahiber.

Simpson, B. M., \& Burpee, C. (2014). Adaptation under the "New Normal" of Climate Change: The Future of Agricultural Extention and Advisory Services. Michigan: USAID.

Sisay, N. (2011). Conserving Biodiversity for the Sake of Local People. Why Biosphere Reserves are Ideal Development Instruments for Ethiopia. In: Biosphere Reserves in the Mountains of the World. Excellence in the Clouds? Celebrating 40 years of UNESCO's MAB Programme: an. Vienna: Austrian Academy of Science Press.

Suhr, D. D. (n.d). Prinicipal Component Analysis vs. Explratory Factor Analysis. SUGI 30 (p. 11). Colorado: sas.com. Retrieved February 25, 2016, from http://www2.sas.com/proceedings/sugi30/203-30.pdf

Taylor, M. (1987). The Possibility of Cooperation. Cambridge: Cambridge University Press and Norwegian University Press.

Teketay, D. (2004). Forestry Research in Ethiopia: Past, Present and Future. In G. Balcha, K. Yeshitela, \& T. Bekele (Ed.), Proceedings of a National Conference on Forest Resources of Ethiopia: Status, Challenges and Opportunities (pp. 1-39). Addis Ababa: IBC.

Teketay, D. (2004-2005). Causes and consequences of dryland forest degradation in Sub-Saharan Africa. Walia, 24, 3-20.

Tongco, M. D. (2007). Purposive Sampling as a Tool for Information Selection. Ethnobotany Research \& Applications, 147-158. Retrieved November 25, 2015, from http://scholarspace.manoa.hawaii.edu/bitstream/ handle/10125/227/I1547-3465-05-147.pdf

Tscharntke, T., Clough, Y., Wanger, T. C., Jackson, L., Motzke, I., Perfecto, I., ... Whitbread, A. (2012). Global food security, biodiversity conservation and the future. Elsevier, 53-59.

UNESCO. (2011). Kafa Biosphere Reserve. Retrieved November 26, 2015, from UNESCO website: http://www.unesco.org/new/en/natural-sciences/environment/ecological-sciences/biosphere-reserves/africa/ ethiopia/kafa/

UNESCO. (2012). Sheka Forest. Retrieved January 24, 2016, from http://www.unesco.org/new/en/ natural-sciences/environment/ecological-sciences/biosphere-reserves/africa/ethiopia/sheka-forest/

Woody Biomass Inventory and Strategic Planing Project [WBISPP]. (2004). Forest Resources of Ethiopia. Addis Ababa: Ministry of Agriculture and Rural Development.

World Resources Institute [WRI]. (2003). Decisions for the Earth: Balance, Voice, and Power. Washington D.C. 2002: World Resources Institute.

\section{Copyrights}

Copyright for this article is retained by the author(s), with first publication rights granted to the journal.

This is an open-access article distributed under the terms and conditions of the Creative Commons Attribution license (http://creativecommons.org/licenses/by/3.0/). 